\title{
KEPRIBADIAN DAN EFIKASI DIRI DENGAN MOTIVASI BELAJAR SISWA KELAS V SEKOLAH DASAR
}

\author{
Jani Natasari Sinulingga \\ Dosen PGSD Universitas Mutiara Nusantara Medan \\ Email : natasarij@gmail.com
}

\begin{abstract}
Abstrack: This research is one korelasional's research that aims to find personality relationship and efikasi self with learned motivation. Childrens living situation at evacuation impactedding to them psychological aspect, notably deep aspect motivates to study. Base hypothesis already being formulated, personality and efikasi self assumed in reference to student studying motivation. This research utilize survey's method, 95 student braze $\mathrm{v}$ elementary schools at posko evacuation is chosen at random. Instrument as kuesioner is validated through expertise and count quiz Pearson Product Moment and reliabilitas's quiz is done by use of Alpha Cronbach . Hypothesis verification is done with analisis regression via tests $\mathrm{f}$ and find mass media model amaan is regression, and correlation coefficient among variable configurational, efikasi self with belajarHasil's motivation research points out that relationship among configurational with learned motivation is $.816(\alpha .001)$. Partial correlation is $.629(\alpha$. $001)$ among personality by motivates studying if done by pengontrolan to efikasi's variable self. Relationship among efikasi self with learned motivation is .674( $\alpha, .001)$. kprelasi's coefficient efikasi's partial self with learned motivation if variable configurational being controlled is $.111(\alpha, .05)$. Found by configurational correlation coefficient and efikasi self with learned motivation is .819 $(\alpha, .001)$.
\end{abstract}

Key word: personality, efikasi self, learned motivation

\begin{abstract}
Abstrak : Penelitian ini adalah sebuah penelitian korelasional yang bertujuan untuk menemukan hubungan kepribadian dan efikasi diri dengan motivasi belajar.Situasi hidup anak-anak di pengungsian berdampak terhadap aspek psikologis mereka, khususnya dalam aspek motivasi belajar.Berdasarkan hipotesis yang telah dirumuskan, kepribadian dan efikasi diri diasumsikan berhubungan dengan motivasi belajar siswa.Penelitian ini menggunakan metode survey, 95 siswa kelas V sekolah dasar di posko pengungsian dipilih secara acak.Instrumen berupa kuesioner divalidasi melalui uji kepakaran dan perhitungan Pearson Product Moment dan uji reliabilitas dilakukan dengan menggunakan Alpha Cronbach. Verifikasi hipotesis dilakukan dengan analisis regresi melalui uji $\mathrm{F}$ dan menemukan model persamaan regresi, dan koefisien korelasi antara variabel kepribadian, efikasi diri dengan motivasi belajarHasil penelitian menunjukkan bahwa hubungan antara kepribadian dengan motivasi belajar adalah $.816(\alpha .001)$. Korelasi parsial adalah .629 $(\alpha, .001)$ antara kepribadian dengan motivasi belajar jika dilakukan pengontrolan terhadap variabel efikasi diri.Hubungan antara efikasi diri dengan motivasi belajar adalah .674 ( $\alpha, .001)$. Koefisien kprelasi parsial efikasi diri dengan motivasi belajar jika variabel kepribadian dikontrol adalah $.111(\alpha, .05)$. Ditemukan koefisien korelasi kepribadian dan efikasi diri dengan motivasi belajar adalah $.819(\alpha, .001)$.
\end{abstract}

Kata Kunci: kepribadian, efikasi diri, motivasi belajar 
Kepribadian Dan Efikasi Diri Dengan

Motivasi Belajar Siswa

Jani Natasari Sinulingga

Kepribadian adalah gambaran cara teori kepribadian agar gangguanseseorang bertingkah laku terhadap gangguan yang biasa muncul pada lingkungan sekitanya, yang terlihat dari kebiasaan berfikir, sikap dan minat, serta pandangan hidupnya yang khas untuk mempunyai keajegan.

$$
\text { Karena dalam kehidupan }
$$

manusia sebagai individu ataupun makhluk social, kepribadian senantiasa mengalami warna-warni kehidupan.Ada kalanya senang, tentram, dan gembira.Akan tetapi pengalaman hidup membuktikan bahwa manusia juga kadang-kadang mengalami hal-hal yang pahit gelisah frustasi dan sebagainya. Ini menunjukan bahwa manusia mengalami dinamika kehidupan.

Kepribadian perilaku seseorang. Kita bisa tahu apa yang sedang diperbuat seseorang dalam situasi tertentu berdasarkan dpengalamn diri kita sendiri. Hal ini karena dalam banyak segi, setiap orang adalah unik, khas. Oleh karena itu kita membutuhkan sejenis kerangka acuan untuk memahami dan menjelaskan tingkah laku diri sendiri dan orang lain. Kita harus memahami definisi kepribadian serta bagaiman kepribadian itu terbentuk.Untuk itu kita membutuhkan teori-teori tingkah laku, kepribadian setiap individu dapat dihindari.

Mempelajari kepribadian merupakan hal yang menarik karena dinamika pengetahuan mengenai diri kita sendiri secara otomatis akan bertambah. Hal ini karena hakikatnya manusia adalah yang ada dan tumbuh berkembang dengan kepribadian yang menyertai setiap langkah dalam hidupnya.

Setiap tindakan individu digerakkan oleh sebuah dorongan yang berasal dari dalam ataupun luar diri individu tersebut dalam rangka mencapai sebuah tujuan.Demikian halnya dalam pembelajaran, siswa memilih, memutuskan dan melakukan suatu tindakan yang digerakkan oleh suatu dorongan untuk mencapai tujuan pembelajaran.Dorongan tersebut dapat distimulasi oleh faktor dalam dan luar diri siswa.Oleh para pakar pendidikan dan perilaku organisasi, dorongan ini disebut dengan istilah motivasi.

Santrock menjelaskan (2006:414), motivasi melibatkan proses-proses yang mengaktifkan mengarahkan dan mempertahankan perilaku. Oleh karena itu, perilaku yang termotivasi adalah 
perilaku yang diaktifkan, diarahkan dan dipertahankan. Dengan pemahaman lain, motivasi belajar dalam diri siswa harus dipantik, diberikan tujuan yang jelas sehingga pada akhirnya dapat tercapai sebuah tujuan. Motivasi belajar harus ada mulai dari awal hingga akhir pembelajaran.

Dikatakan oleh Colquitt, LePine dan Wesson (2015:168) motivasi didefinisikan sebagai sebuah dorongan berenergi yang berasal dari dalam dan luar diri individu, dorongan yang menjadi awal usaha, dan menentukan arah, intensitas dan ketekunan.

Motivasi timbul sebagai sebuah dorongan yang berenergi berasal dari luar maupun dalam diri siswa. Pernyataan ini berarti bahwa motivasi dapat muncul di dalam diri siswa dikarenakan adanya kesadaran akan pemenuhan kebutuhan yang menyangkut dengan kepentingan diri siswa. Motivasi juga dapat muncul pada diri siswa ketika adanya dorongan dari luar diri siswa dalam bentuk ganjaran ataupun hukuman. Motivasi ini akan terwujud dari usaha dan kegigihan siswa untuk menyelesaikan tugas dan mencapai tujuan pembelajaran. Motivasi belajar menjadi sebuah faktor penting dalam mencapai keberhasilan siswa dalam pembelajaran.

Lemah kuatnya motivasi belajar dipengaruhi oleh berbagai faktor yang ada dalam diri siswa maupun di luar diri
siswa.Salah satu yang terkait dengan motivasi belajar siswa adalah kepribadian siswa itu sendiri.

Setiap individu dianugerahi dengan sifat-sifat unik dan berbeda.Sifat-sifat ini diyakini terbentuk oleh faktor keturunan (nature/heredity) dan faktor lingkungan (nurture).Respon yang diberikan individu untuk beradaptasi dengan lingkungannya bergantung kepada sifat-sifat yang dimiliki individu tersebut. Anak yang sering khawatir dan cemas akan memberi respon yang berbeda dengan anak yang percaya diri dan suka bersosialisasi ketika masuk ke dalam lingkungan yang baru. Kepribadian siswa berkontribusi terhadap respon yang ditunjukkannya di dalam situasi pembelajaran.

Menurut George \& Jones (2005:39), kepribadian adalah pola dari cara menetap relatif seseorang dalam berpikir, merasakan, dan berperilaku. Dilanjutkan oleh George \& Jones (2005:39), sebagian kepribadian dibentuk sejak lahir (nature), atau diturunkan oleh orangtua. Gen yang diwariskan oleh orangtua mempengaruhi terbentuknya kepribadian individu. Setengah dari variasi kepribadian individu diperoleh sejak lahir, maka tidak mengherankan jika kepribadian tetap stabil selama 5 sampai 10 tahun. George \& Jones (2005:39) juga menambahkan bahwa 
Kepribadian Dan Efikasi Diri Dengan

Motivasi Belajar Siswa

Jani Natasari Sinulingga

kepribadian terus berkembang seiring kepribadian neurotisme akan cenderung perjalanan waktu (nurture), sebagai respon terhadap ketat atau longgarnya aturan yang diberikan orangtua kepada anak, jumlah anak dalam lingkungan keluarga, tuntutan orangtua dan guru terhadap anak, kesuksesan ataupun kegagalan memperoleh teman atau pekerjaan, dan bahkan budaya dimana individu dibesarkan dan hidup sebagai orang dewasa. Kesemuanya membentuk kepribadian.

Salah satu model kepribadian adalah model The Big Five Personality yang menempatkan lima sifat kepribadian, termasuk di dalamnya extraversion, agreeableness, conscientiousness, neuroticis $m$ (emotional stability) dan openness to experience (Gareth \& Jones, 2005:43).

Menurut Luthans kepribadian ekstravet (extraversion) memiliki karakteristik mudah bergaul, ramah, suka berbicara dan percaya diri.Keramahan (agreeableness) memiliki karakteristik mampu bekerja sama (kooperatif), hangat, peduli, sopan, dapat dipercaya.Kesungguhan(conscientiousnes) memiliki karateristik dapat dipercaya, suka bekerja keras, teratur, disiplin, tekun dan bertanggung jawab, kepribadian yang memiliki emosi yang stabil akan berkarakteristik tenang, merasa aman, bahagia dan tidak khawatir. Sebaliknya merasa tidak aman, sedih dan selalu khawatir, dan keterbukaan terhadap pengalaman baru (openness to experience) memilki karakteristik rasa ingin tahu, cerdas, kreatif, berbudaya, memiliki jiwa seni, fleksibel dan imajinatif.

Keakuratan kepribadian seseorang berkontribusi kepada motivasi belajar siswa.Pribadi ekstravet adalah pribadi yang suka bersosialisasi, suka berbicara, memiliki keinginan kuat dan cenderung berambisi. Sehingga, ketika siswa adalah siswa yang ekstravet maka motivasi belajar yang dimilikinya akan lebih tinggi karena didukung oleh ambisi dan keinginan kuat untuk mencapai tujuan pembelajaran.

Sifat ramah (agreeableness) adalah sifat suka bekerja sama, ramah, hangat dan sopan. Siswa yang mampu bekerja sama dengan teman-teman sebayanya dalam belajar akan mencapai tujuan pembelajaran yang lebih optimal. Dikarenakan dalam setiap proses pembelajaran di kelas, siswa diharapkan mampu bekerja sama, berkomunikasi dan belajar bersama dalam menyelesaikan sebuah tugas. Untuk itu siswa yang memiliiki sifat mampu bekerja sama memiliki motivasi belajar yang tinggi.

Dimensi kepribadian berikutnya adalah dimensi kesungguhan yang berkarakteristik bekerja keras, bertanggung 
jawab, terorganisir, tekun dan dapat dipercaya.Siswa yang memiliki kepbribadian ini memiliki motivasi belajar yang tinggi.Dikatakan bahwa motivasi adalah dorongan untuk mencapai sebuah tujuan dengan melakukan tindakan berorientasi tujuan secara berkelanjutan. Dengan demikian, siswa yang tekun, pekerja keras, teratur dan bertanggung jawab adalah siswa yang memiliki motivasi belajar yang tinggi. Seperti yang dipaparkan oleh Judge dan Ilies (2002:801) bahwa kesungguhan berkorelasi secara positif dengan motivasi berprestasi.

Neurotisme adalah dimensi keempat kepribadian yang bercirikan mudah khawatir, depresi, tegang dan sering merasa tidak aman.Lawan dari neurotisme adalah stabilitas emosi yang memiliki ciri kepribadian tenang, santai, stabil dan merasa aman.Siswa yang memiliki emosi stabil selama pembelajaran dapat menjaga motivasi belajarnya tetap konsisten.Hal ini berarti rasa tenang, aman dan kestabilan emosi siswa memampukannya untuk tetap tekun dalam mencapai tujuan pembelajaran. Dalam sebuah jurnal penelitian (Judge \& Ilies, 2002:801) yang mencari hubungan antara neurotisme dengan motivasi berprestasi, ditemukan bahwa neurotisme berkorelasi secara negatif dengan motivasi berprestasi.
Dimensi kepribadian yang terakhir adalah keterbukaan terhadap pengalaman baru (openness to experience).Sifat kepribadian ini adalah memiliki rasa ingin tahu, cerdas, kreatif, berbudaya, memiliki jiwa seni, fleksibel dan imajinatif. Motivasi belajar yang tinggi akan memicu rasa ingin tahu yang tinggi, fleksibiltas dalam menghadapi situasi pembelajaran yang menantang dan penyelesaian masalah. Siswa yang memiliki kepribadian terbuka kepada pengalaman baru memiliki motivasi belajar yang tinggi.

Efikasi diri juga menjadi faktor berikutnya yang memiliki keterkaitan dengan motivasi belajar.Efikasi diri adalah keyakinan dalam diri seseorang untuk menyelesaikan tugas-tugas yang diberikan kepadanya. Menurut Santrock (2011:450), efikasi diri adalah keyakinan bahwa "Aku Bisa". Siswa dengan efikasi diri yang tinggi akan mengeluarkan pernyataan, "Aku tahu bahwa aku mampu menguasai materi ini”, dan "Aku akan melakukan yang terbaik pada saat aktivitas ini berlangsung”.

Pernyataan Santrock mengenai efikasi diri ini menekankan pada keyakinan siswa untuk menguasai situasi yang dihadapinya. Siswa yang memiliki efikasi diri tinggi akan mampu menyelesaikan tugas-tugas yang menantang. Efikasi diri akan berpengaruh kepada pencapaian siswa. Jika 
Kepribadian Dan Efikasi Diri Dengan

Motivasi Belajar Siswa

Jani Natasari Sinulingga

siswa yakin bahwa sebuah tugas dapat menghitung reliabilitas dengan diselesaikan maka motivasi untuk menyelesaikan tugas tersebut akan menguat.

\section{METODE}

Penelitian ini bertujuan untuk mengetahui 1) Hubungan kepribadian dengan motivasi belajar siswa kelas V SD di posko pengungsian Gunung Sinabung, Kabupaten Karo, Sumatera Utara, 2) Hubungan efikasi diri dengan motivasi belajar siswa kelas V SD di posko pengungsian Gunung Sinabung, Kabupaten Karo, Sumatera Utara dan 3) Hubungan kepribadian dan efikasi diridengan motivasi belajar siswa kelas V SD di empat posko pengungsian Gunung Sinabung, Tanah Karo, Sumatera Utara. Responden dipilih dengan membatasi sampling frame sebanyak 100 siswa dan dengan menggunakansimple random samplingmemilih 95 siswa sebagai sampel dari jumlah total responden.

Pengumpulan data dengan menggunakan kuesioner untuk masingmasing variabel. Selanjutnya, untuk mendapatkan data yang sahih maka instrumen tersebut diuji pkar yang dilanjutkan dengan validitas empiris, untuk menguji validitas dengan menggunakan rumus pearson product momentdan

menggunakan Alpha Cronbach.

Kegiatan dalam analisis data dalam penelitian ini meliputi analisis statistika deskriptif dan inferensial. Pengujian hipotesis dilakukan melalui uji $\mathrm{F}$ regresi sederhana dan ganda, dan uji korelasi untuk mengetahui kekuatan hubungan antar variabel setelah melalui uji normalitas menggunakan galat taksiran dan uji homogenitas menggunakan uji Barlett.

\section{HASIL}

Hasil penelitian yang diperoleh setelah dinyatakan memenuhi persyaratan analisis statistik, maka pengujian hipotesis dilakukan dan memperoleh hasil perhitungan yang sebagaimana tersaji dalam tabel 2 berikut.

\section{Hubungan Kepribadian dengan \\ Motivasi Belajar}

perhitungan analisis regresi sederhana berdasarkan data variabel motivasi belajaratas kepribadian menghasilkan regresi $b$ sebesar 0,55 dan konstanta a sebesar 6,81. Dengan demikian bentuk hubungan antara kedua variabel dapat digambarkan melalui persamaan regresi $\hat{Y}$ $=6,81+0,55 \mathrm{X}_{1}$.

Sebelum digunakan untuk keperluan prediksi, persamaan regresi ini harus memenuhi syarat uji keberartian 
(signifikansi) dan uji kelinieran. Oleh karena itu untuk mengetahui derajat keberartian dan kelinieran regresi, diperoleh $F_{\text {hitung }}=185,608>F_{\text {tabel }}=3,94(\mathrm{db}=(1,93)$, $\alpha=0,05)$. Dengan demikian persamaan regresi $\hat{\mathrm{Y}}=6,81+0,55 \mathrm{X}_{1}$ signifikan. Berdasarkan hasil uji linieritas persamaan garis regresi di atas diperoleh $F_{\text {hitung }}=0,927$ $<\mathrm{F}_{\text {tabel }}=1,47557,(\mathrm{db}=(39,54), \alpha=0,05)$.

Hal ini berarti persamaan regresi motivasi belajar $(\mathrm{Y})$ atas kepribadian $\left(\mathrm{X}_{1}\right)$ adalah linier. Dengan kata lain terdapat hubungan antara kepribadian dengan motivasi belajar. Model regresi yang diperoleh mengandung arti bahwa apabila kepribadian ditingkatkan satu poin, maka motivasi belajar cenderung meningkat sebesar 0,55 poin pada konstanta 6,81 .

Kekuatan hubungan antara variabel kepribadian $\left(\mathrm{X}_{1}\right)$ dengan hasil motivasi belajar (Y) ditunjukkan oleh koefisien korelasi $\left(\mathrm{r}_{\mathrm{x} 1 \mathrm{y}}\right)$ sebesar 0,816, dan signifikan pada $\alpha<0.001$, menunjukkan koefisien korelasi $r_{x 1 y}$ signifikan.Koefisien korelasi dan signifikansi kepribadian dengan motivasi belajar

Signifikansi koefisien korelasi di atas ditandai dengan taraf signifikansi $\alpha<$ 0.001, sehingga koefisien korelasi kepribadian dengan motivasi belajar terbukti signifikan. Hal ini membuktikan koefisien korelasi antara kepribadian dengan motivasi belajar signifikan.Dengan demikian hipotesis penelitian yang menyatakan terdapat hubungan positif antara kepribadian dengan motivasi belajar diterima. Dengan kata lain makin akuratkepribadian siswa maka makin kuatmotivasi belajar.

Koefisien determinasi merupakan kuadrat dari koefisien korelasi antara kepribadian dengan motivasi belajar yaitu $\left(\mathrm{r}_{\mathrm{y} 1}\right)=(.816)$. Artinya $66,61 \%$ variasi yang terjadi pada motivasi belajar dapat dijelaskan oleh variasi kepribadian.

Uji koefisien korelasi parsial adalah derajat hubungan dalam satu atau multi variabel bebas dengan variabel terikat melalui pengontrolanvariabel bebas lainnya. Pengontrolan variabel bebas lainnya dimaksudkan untuk menentukan derajat hubungan antara satu variabel bebas tertentu (misal $\mathrm{X}_{1}$ ) dengan variabel terikat $\mathrm{Y}$, dimana variabel bebas lainnya $\left(\mathrm{X}_{2}\right)$ dibuat konstanta atau dikendalikan. Pengujian hipotesis dilakukan dengan menggunakan SPSS versi 20.00, diperoleh korelasi parsial positif sebesar 0,629, $\mathrm{n}=$ 95, $\mathrm{db}=92$, dan $\alpha<0.001$. diindikasikan kepribadian memiliki hubungan yang cukup kuat dengan motivasi belajar jikavariabel efikasi diri dikontrol.

Hasil penelitian menunjukkan bahwa terdapat hubungan positif dan signifikan 
Kepribadian Dan Efikasi Diri Dengan

Motivasi Belajar Siswa

Jani Natasari Sinulingga

antara kepribadian dengan motivasil belajar. Hal ini ditunjukkan dengan hasil uji signifikansi dan linieritas persamaan regresi $\mathrm{Y}$ atas $\mathrm{X}_{1}$ dan koefisien korelasi dengan signfikansi $\alpha<0,01$ yang menolak hipotesis tidak terdapat hubungan antara kepribadian dengan motivasi belajar. Pola hubungan yang linier antara kedua variabel ini dinyatakan oleh persamaan regresi $\hat{Y}=6,81$ $+0,55 \mathrm{X}_{1}$.Persamaan ini menunjukkan bahwa setiap perubahan satu skor pada kepribadian menyebabkan peningkatan motivasi belajar sebesar 0,55 pada konstanta 6,81 .

Hasil analisis korelasi sederhana antara kepribadian dengan motivasi belajar diperoleh koefesien korelasi $\left(\mathrm{r}_{\mathrm{y} .1}\right)=0,816$, signifikan pada $\alpha<0,001$. Ini memberikan pengertian bahwa keterkaitan antara kepribadian dengan motivasi belajar adalah positif, artinya makin akurat kepribadian maka makin kuat pula motivasi belajar. Sebaliknya makin tidak akurat kepribadian maka makin lemah pula motivasi belajar.

\section{Hubungan}

Efikasi

Diri

\section{denganMotivasi Belajar}

Perhitungan analisis regresi sederhana berdasarkan data variabel motivasi belajar atasefikasi diri menghasilkan regresi b sebesar 0,89 dan konstanta a sebesar 44,1. Dengan demikian bentuk hubungan antara kedua variabel dapat digambarkan melalui persamaan regresi $\hat{Y}=44.1+0.89 \mathrm{X}_{2}$.

Untuk mengetahui derajat keberartian dan kelinieran regresi, dilakukan uji keberartian dan hasilnya diperoleh $\mathrm{F}_{\text {hitung }}=77,319>\mathrm{F}_{\text {tabel }}=3,94$, $(d b=(1,93), \alpha=0,05)$. Dengan demikian persamaan regresi $\hat{\mathrm{Y}}=44.1+0.89 \mathrm{X}_{2}$ signifikan.

Berdasarkan hasil uji linieritas persamaan garis regresi di atas diperoleh $\mathrm{F}_{\text {hitung }}=1,248<\mathrm{F}_{\text {tabel }}=1,7001,(\mathrm{db}=$ $(70,94), \alpha=0,05)$. Hal ini berarti persamaan regresi motivasi belajar (Y) atas efikasi diri $\left(\mathrm{X}_{2}\right)$ adalah linier. Dengan kata lain terdapat hubungan antara efikasi diri dengan motivasi belajar. Model regresi yang diperoleh mengandung arti bahwa apabila efikasi diri ditingkatkan satu poin, maka motivasi belajar cenderung meningkat sebesar 0,89 poin pada konstanta 44,1.

Kekuatan hubungan antara variabel efikasi $\left(\mathrm{X}_{2}\right)$ dengan hasil motivasi belajar (Y) ditunjukkan oleh koefisien korelasi $\left(r_{\mathrm{x} 2 \mathrm{y}}\right)$ sebesar 0,674, $\alpha<0,001$. Koefisien korelasi dan signifikansi efikasi diri dengan motivasi belajar dapat ditelaah

Signifikansi koefisien korelasi di atas ditandai dengan taraf signifikansi $\alpha<0.001$, sehingga koefisien korelasi efikasi diri dengan motivasi belajar terbukti signifikan.Dengan demikian hipotesis 
penelitian yang menyatakan terdapat hubungan positif antara efikasi diri dengan motivasi belajar diterima. Dengan kata lain makin tinggiefikasi diri siswa akan makin kuatmotivasi belajar.

Koefisien determinasi merupakan kuadrat dari koefisien korelasi antara efikasi dengan motivasi belajar yaitu $\left(\mathrm{r}_{\mathrm{y} 2}\right)=$ (.674) Artinya 45,40\% variasi yang terjadi pada motivasi belajar dapat dijelaskan oleh variasi efikasi diri.

Uji koefisien korelasi parsial adalah derajat hubungan dalam satu atau multi variabel bebas dengan variabel terikat melalui pengontrolan variabel bebas lainnya. Pengontrolan variabel bebas lainnya dimaksudkan untuk menentukan derajat hubungan antara satu variabel bebas tertentu (misal $\mathrm{X}_{2}$ ) dengan variabel terikat $\mathrm{Y}$, dimana variabel bebas lainnya $\left(\mathrm{X}_{1}\right)$ dibuat konstanta atau dikendalikan. Pengujian hipotesis dilakukan dengan menggunakan SPSS, diperoleh korelasi parsial positif sebesar $0,111, \mathrm{n}=95, \mathrm{db}=$ 92, dan $\alpha<0,05$. diindikasikan efikasi diri memiliki hubungan yang lemah dengan motivasi belajar ketikavariabel kepribadiandikontrol.

Hasil penelitian menunjukkan bahwa terdapat hubungan positif dan signifikan antara efikasi diri dengan motivasil belajar. Hal ini ditunjukkan Hal ini ditunjukkan dengan hasil uji signifikansi dan linieritas persamaa regresi $\mathrm{Y}$ atas $\mathrm{X}_{2}$ dan koefisien korelasi dengan signfikansi $\alpha$ $<0,01$ yang menolak hipotesis tidak terdapat hubungan antara efikasi diri dengan motivasi belajar. Pola hubungan yang linier antara kedua variabel ini dinyatakan oleh persamaa $\mathrm{n}$ regresi $\hat{\mathrm{Y}}=$ $44.1+0.89 \mathrm{X}_{2}$. Persamaan ini menunjukkan bahwa setiap perubahan satu skor pada efikasi diri menyebabkan peningkatan motivasi belajar sebesar 0,89 pada konstanta 44,1.

Hasil analisis korelasi sederhana antara efikasi diri dengan motivasi belajar diperoleh koefesien korelasi $\left(r_{\mathrm{y} .2}\right)=0,674$ signifikan pada $\alpha<0,001$. Nilai ini memberikan pengertian bahwa keterkaitan antara efikasi diri dengan motivasi belajar adalah positif, artinya makin tinggi efikasi diri, maka makin kuat pula motivasi belajar.Sebaliknya semakin rendah, maka semakin lemah pula motivasi belajar.

\section{Hubungan Kepribadian dan Efikasi Diri dengan Motivasi Belajar}

Hasil analisis regresi ganda antara kepribadian dan efikasi diri denganmotivasi belajar diperoleh harga koefesien arah regresi ganda dengan konstanta $a_{0}$ sebesar 7,57, koefisien arah regresi $b_{1}$ sebesar 0,49 untuk kepribadian ,dan $\mathrm{b}_{2}$ sebesar 0,13 untuk efikasi diri. Dengan demikian bentuk 
Kepribadian Dan Efikasi Diri Dengan

Motivasi Belajar Siswa

Jani Natasari Sinulingga

hubungan antara kedua variabel bebas

Hasil penelitian menunjukkan bahwa secara bersama-sama dengan variabel terikat tersebut dapat digambarkan melalui persamaan regresi $\hat{\mathrm{Y}}=7,57+0,49 \mathrm{X}_{1}+$ $0,13 \mathrm{X}_{2}$. diperoleh $\mathrm{F}_{\text {hitung }}=93,513>\mathrm{F}_{\text {tabel }}=$ $3,1, \quad(d b=(2,92), \quad \alpha=0,05)$,Dengan demikian persamaan regresi $\hat{Y}=7,57+$ $0,49 X_{1}+0,13 X_{2}$ signifikan. Hal ini menandakan terdapat hubungan yang signifikan antara kepribadian dan efikasi diri dengan motivasi belajar.

Kekuatan hubungan antara kepribadian dan efikasi diri dengan motivasi belajar (ry.12) diperoleh 0.819, $\alpha<$ 0.001 , koefisien korelasi kepribadian dan efikasi diri dengan motivasi belajar menunjukkan bahwa koefisien korelasi signifikan dengan , $\alpha<0.001$. Koefesien determinasi (ry.12) adalah sebesar $(\text { ry.12) })^{2}=$ $(0,819)^{2}$ Artinya $67,03 \%$ variasi yang terjadi pada motivasi belajar dapat dijelaskan oleh variasi kepribadian dan efikasi diri. Koefisien determinasi yang cukup besar yaitu 67,03\% merupakan nilai persentasi sumbangan kepribadian dan efikasi diri dengan motivasi belajar berarti selebihnya merupakan sumbangan varabel lain. Dengan demikian hipotesis alternatif ketiga diterima. 
0,6703. Secara statistik nilai ini memberikan makna bahwa 67,03\% variasi yang terjadi pada motivasi belajar dapat dijelaskan oleh kepribadian dan efikasi diri

\section{PEMBAHASAN}

Luthans (2011: 125) berpendapat bahwa kepribadian adalah cara individu memberi pengaruh terhadap orang lain dan cara individu memahami dan meliihat dirinya sendiri, demikian juga pola sifat dari dalam dan luar diri yang dapat diukur serta interaksi individu dengan situasi yang dihadapinya.Kepribadian terbagi ke dalam lima dimensi yaitu ekstravet, keramahan, kesungguhan, stabilitas emosi dan keterbukaan terhadap pengalaman baru.

Keakuratan dimensi-dimensi ini dalam kepribadian siswa memberi kontribusi kepada motivasi belajarnya. Sebagai contoh, siswa yang enggan bergaul, tidak memiliki keinginan yang kuat, tidak berambisi, dan tidak berminat untuk bergabung atau memimpin sebuah kelompok belajar akan lemah motivasinya untuk belajar lebih giat. Demikian juga dengan siswa yang menolak, malu dan takut untuk mencoba hal-hal baru pada saat belajar mengindikasikan lemahnya motivasi belajar. Berkaitan dengan stabilitas emosi yang labil juga mengakibatkan individu mudah stres, tegang dan tertekan dalam berbagai situasi. Siswa dengan neurotisme seperti ini akan kesulitan untuk memelihara motivasi belajarnya untuk konsisten atau bahkan untuk meningkatkannya.

Ketidakstabilan ini dapat menyebabkan perasaan mudah menyerah. Keakuratan dimensi kesungguhan dalam diri siswa akan mencerminkan ketangguhan dorongan dari dalam dirinya untuk mencapai tujuan. Diperkuat oleh sebuah jurnal internasional tentang hubungan kepribadian dengan motivasi belajar bahwa setiap dimensi kepribadian pada dasarnya memiliki hubungan dengan motivasi belajar denganbesaran koefisien korelasi yang berbeda untuk setiap dimensinya. Sehingga memang tidak dapat dipungkiri bahwa kepribadian memberikan kontribusi positif kepada motivasi belajar siswa (Ariani, 2013: 34).

Besarnya sumbangan atau kontribusi variabel kepribadiankepadamotivasi belajar dapat diketahui dengan jalan mengkuadratkan perolehan koefesien sederhana $(0,816)^{2}$ yaitu sebesar 0,6661 . Secara statistik nilai ini memberikan makna bahwa $66,61 \%$ variasi yang terjadi pada motivasi belajar dapat dijelaskan oleh kepribadian. Oleh karena itu, kepribadian memiliki hubungan yang positif dengan motivasi belajar. Dengan demikian, variabel kepribadian merupakan salah satu faktor 
Kepribadian Dan Efikasi Diri Dengan

Motivasi Belajar Siswa

Jani Natasari Sinulingga

yang harus diperhatikan untuk meningkatkan motivasi belajar siswa.

Selanjutnya pada pengujian korelasi parsial kepribadian dengan motivasi belajar dengan mengontrol efikasi diri diperoleh koefisien $r_{y .1 .2}$ sebesar 0,629 dan koefisien determinasinya $r_{y .12}$ sebesar 0,3956 hasil pengujian ini memberikan penjelasan bahwa 39,56\% variasi yang terjadi pada motivasi belajar dapat dijelaskan oleh variabel kepribadian dengan mengontrol variabel efikasi diri.

Hasil pengujian analisis statistik tersebut menunjukkan bahwa kepribadian memberikan kontribusi yangsignifikan terhadap motivasi belajar dimana makin akurat kepribadian maka makin kuat pulamotivasi belajar.Sebaliknya makin tidak akurat kepribadian maka makin lemah pula motivasi belajar

Efikasi diri, yang menjadi sentral teori sosial Albert Bandura, adalah keyakinan individual terhadap kemampuan dirinya untuk menyelesaikan sebuah tugas secara efektif Quick \& Nelson, 2013: 178). Efikasi diri diperoleh melalui pengalaman pribadi ketika berhasil menyelesaikan tugas ataupun berhasil bangkit dari kegagalan. Efikasi diri juga dapat meningkat dengan belajar dari pengalaman pribadi orang lain, dengan melihat kesamaan-kesamaan yang ada dan terjadi pada orang lain dapat meningkatkan keyakinan diri untuk berhasil menyelesaikan tugas-tugas. Selanjutnya pada pengujian korelasi parsial efikasi diridengan kepribadian dan motivasi belajar diperoleh koefisien $r_{y} .12$ sebesar 0,111 dan koefisien determinasinya $r_{y} 1.2$ sebesar 0,0123 hasil pengujian ini memberikan penjelasan bahwa $1,23 \%$ variasi yang terjadi pada motivasi belajar dapat dijelaskan oleh variabel efikasi diri dengan mengontrol variabel kepribadian.

Penemuan ini sejalan dengan hasil temuan Bandura, Zimmerman, dan Martinez-Ponz (1992: 674) yang menyatakan bahwa efikasi diri akan memotivasi perolehan akademik dengan cara mempengaruhi penyusunan tujuan pribadi. Hasil pengujian analisis statistik tersebut menunjukkan bahwa efikasi diri memberikan kontribusi yang signifikan terhadap motivasi belajar, dimana makin tinggi efikasi diri maka makin kuatpula motivasi belajar.Sebaliknya makin rendah efikasi diri maka makin lemah pula motivasi belajar.

Kepribadian dan efikasi diri memiliki hubungan positif dengan motivasi belajar. Dengan demikian, variabel kepribadian dan efikasi diri merupakan dua faktor yang harus diperhatikan untuk meningkatkan motivasi belajar

\section{SIMPULAN}


Berdasarkan paparan di atas, diperoleh temuan sebagai berikut: pertama, terdapat hubungan positif antara kepribadian dengan motivasi belajar siswa.Kedua, terdapat hubungan positif antara efikasi diri dengan motivasi belajar siswa. Ketiga, terdapat hubungan antara kepribadian dan efikasi diri secara bersamasama dengan motivasi belajar.

Oleh karena itu, secara umum dapat disimpulkan bahwa Kepribadian adalah keseluruhan cara di mana seorang individu bereaksi dan berinteraksi dengan individu lain. Kepribadian paling sering dideskripsikan dalam istilah sifat yang bisa diukur yang ditunjukkan oleh seseorang.

Alasan paling penting mengapa perlu mengetahui cara menilai kepribadian adalah karena penelitian menunjukkan bahwa testes kepribadian sangat berguna dalam membuat keputusan apa yang akan di lakukannya. Dan dapat di tarik kesimpulan makin akurat kepribadian siswa, maka makin kuat motivasi belajar yang dimilikinya. Demikian juga dengan efikasi diri, makin tinggi efikasi diri siswa, maka makin kuat motivasi belajar.Makin akurat dan tinggi kepribadian dan efikasi diri secara bersama-sama, maka makin kuat motivasi belajar siswa.Dapat disimpulkan bahwa kepribadian dan efikasi diri berkontribusi kepada kuat lemahnya motivasi belajar siswa.

\section{DAFTAR RUJUKAN}

Ariani, D. W. (2013). Personality and Learning Motivation. European Journal of Business and

Management, 26-38.

Barry j. Zimmerman, Albert Bandura, Manuel Martinez-Pons. (1992). Self Motivation for Academic

Attainment: The Role of SelfEfficacy Beliefs and Personal Goal Setting. American Educational

Research Journal , 663-676.

James Campbell \& Debra L.Nelson. (2013).

Principles of Organizational Behavior: Realities and

Challenges. South Western: Cengage. Jason A Colquitt, Jeffrey A. LePine, Michael J. Wesson. (2015). Organizational Behavior: Improving Performance and Commitment in the Workplace. New York: McGraw-Hill Education.

Jennifer M. George, Gareth R. Jones. (2005). Understanding and Managing Organizational Behavior. New Jersey: Pearson.

Luthans, F. (2011). Organizational behavior: An Evidence-Based Approach. New York: McGraw-Hill. 
Santrock, J. W. (2006). Educational

Psychology: Classroom Update

Preparing for PRAXIS tm and

Practice. New York: McGraw-Hill.

Santrock, J. W. (2011). Educational

Psychology: Fifth Edition. New York:

McGraw-Hill.

Timoty A. Judge and Remus Ilies. (2001).

Relationship of Personality to

Motivation: A Meta- Analytic

Review. Journal of Applied

Psychology. 